\title{
Upland Rice Growth after Low-Input Amendments on Upland Soil in West Kalimantan, Indonesia
}

\author{
Sutarman Gafur ${ }^{1 *}$ and Ismahan Umran ${ }^{2}$ \\ 1, 2Department of Soil Science, Faculty of Agriculture, Tanjungpura University \\ Jalan Prof. Dr. Hadari Nawawi, Pontianak, 78124, West Kalimantan, INDONESIA. \\ *e-mail:sutarman.g@faperta.untan.ac.id
}

Received July 26, 2019; Revised September 10, 2019; Accepted 13 September 2019

\begin{abstract}
Upland soils in West Kalimantan that are used for agricultural activities reach about 483,077 ha. However, this land potency has not yet optimally exploited due to poor soil fertility. To increase its productivity, there is a need to invent technology packages that are not only effective but also efficient. This research is designed to study the growth of local selected upland rice and the changes in certain soil properties after low-input fertilization applications. This research was conducted in a green house, Faculty of Agriculture, Tanjungpura University. The laboratory works finished in February 2016. The study was arranged in a Completely Randomized Design. There were 6 treatments and 4 replications. The treatment levels were P0 (no treatment), P1 (7 Mg cow manure ha ${ }^{-1}+300 \mathrm{~kg}$ compound NPK ), P2 (15 Mg cow manure ha ${ }^{-1}+300 \mathrm{~kg}$ compound NPK), P3 (7 Mg rice straw compost ha ${ }^{-1}+300$ compound kg NPK), P4 (15 Mg rice straw compost ha ${ }^{-1}+300 \mathrm{~kg}$ compound NPK), and P5 (600 kg ha- compound NPK). The parameters measured included plant height and dry weight, NPK uptake, soil pH, soil organic C content, and $\mathrm{N}, \mathrm{P}, \mathrm{K}$ contents after soil treatment. The results showed that the local selected upland rice responded well to low-input fertilization treatments, as the response was similar to that of $600 \mathrm{~kg} \mathrm{NPK} \mathrm{ha}^{-1}$. However, treatment P4 left higher base cation residues among all the treatments. Furthermore, the treatments $\mathrm{P} 2$ and P4 were suggested to be further research topics on upland soil of West Kalimantan as these treatments resulted better plant growth, while treatment $\mathrm{P} 4$ had a promising effect on soil base cation residues specifically $\mathrm{Ca}, \mathrm{Mg}$, and $\mathrm{Na}$.
\end{abstract}

Keywords: Cow-manure, rice-straw compost, upland-rice, West Kalimantan

\begin{abstract}
ABSTRAK
Luas lahan kering yang dimanfaatkan untuk kegiatan pertanian di Kalimantan Barat mencapai 483.077 ha. Namun demikian, potensi lahan ini belum digarap secara optimal karena kondisinya yang kurang subur. Untuk meningkatkan produktivitasnya dibutuhkan sebuah paket teknologi yang tidak hanya efektif tetapi juga efisien. Penelitian ini dirancang untuk mempelajari pertumbuhan padi unggul lokal dan perubahan beberapa sifat penting tanah setelah perlakuan pemupukan diberikan. Penelitian ini dilaksanakan di rumah plastik, Fakultas Pertanian, Universitas Tanjungpura. Pekerjaan laboratorium selesai pada bulan Februari 2016. Penelitian ini menggunakan rancangan acak lengkap, dengan 6 perlakuan dan 4 ulangan. Perlakuan terdiri dari P0 (tanpa perlakuan), P1 (7 Mg pupuk kandang sapi ha ${ }^{-1}+300 \mathrm{~kg}$ pupuk NPK), P2 (15 Mg pupuk kandang sapi ha ${ }^{-1}+300 \mathrm{~kg}$ pupuk NPK), P3 (7 Mg kompos jerami ha-1 $+300 \mathrm{~kg}$ pupuk NPK), P4 (15 Mg kompos jerami ha- $+300 \mathrm{~kg}^{-1}$ pupuk NPK), dan P5 (600 kg pupuk NPK $\mathrm{ha}^{-1}$ ). Parameter yang diamati meliputi tinggi dan berat kering tanaman, serapan hara $\mathrm{N}, \mathrm{P}, \mathrm{K}, \mathrm{pH}$ tanah, kandungan C-organik, dan N, P, dan K setelah tanah diberi perlakuan. Hasil penelitian menunjukkan bahwa padi unggul lokal merespon dengan baik terhadap perlakuan dengan input rendah karena menyamai perlakuan $600 \mathrm{~kg}$ pupuk NPK. Namun demikian, perlakuan P4 meninggalkan residu kation basa yang lebih tinggi dibandingkan perlakuan yang lain. Selanjutnya perlakuan P2 dan P4 disarankan untuk menjadi topik yang dikembangkan dalam penelitian di lapangan karena memberikan respon pertumbuhan yang lebih baik. Perlakuan P4 memiliki dampak yang menjanjikan terhadap residu kation basa, terutama $\mathrm{Ca}, \mathrm{Mg}$, dan $\mathrm{Na}$.
\end{abstract}

Kata kunci: Kalimantan Barat, kompos jerami padi, padi lahan kering, pupuk kandang sapi

J Trop Soils, Vol. 24, No. 3, 2019: 119-128

ISSN 0852-257X; E-ISSN 2086-6682 


\section{INTRODUCTION}

The number of upland soil in West Kalimantan that is potential for agricultural crops is about 233,946 ha. The number of available land, especially for upland rice cultivation is about 138,732 ha. However, up to 2013 only about 103,972 ha has been cultivated for upland rice (BPS 2014). At the moment, most of upland rice cultivation practices in West Kalimantan are commonly conducted as shifting cultivation. Recently, the total area of upland rice cultivation tends to increase, although the production level is still relatively low. It shows that the upland rice cultivation practices have become an important part of the traditional lifestyle of lowincome people, especially for ethnic Malay and Dayak in the rural areas of West Kalimantan. As they are known as the predominant ethnic groups living in the rural areas of West Kalimantan, this agricultural issue has become a crucial focus. Not only does it need to be well-discussed, as it involves many aspects of rural life, but it also needs to be better developed to increase the production level of upland rice and in turn increase the people's income levels and prosperity.

Efforts to increase upland rice production and its sustainability have been discussed. However, the efforts made so far are still below the expectations (Regmi and Weber 2000). The proposed solutions to solve the problems varied. Technically, the proposed solutions had different focuses, such as land management and conservation (Killham 2011; Thierfelder et al. 2014), land rehabilitation (Montagnini 2001), and biodiversity (Regmi and Weber 2000; Wolfe 2000; Philips and Wolfe 2005). Another proposed solution was organic farming practice, as it proved to perform better than the conventional practices in improving soil quality regarding both physical and biological properties (Gomiero 2013). From the strategies offered, it could be concluded that there was no one-size-fitsall solution.

It is known that the upland smallholders in West Kalimantan are generally located on marginal lands. Most of the upland soils in this area are low-fertility soils, cultivated with less input crop management and subsistence farming systems. Moreover, smallholders in West Kalimantan are facing both internal and external issues. The internal issues mainly cover the lack of knowledge due to their low level of education and lack of training programs, as well as rural poverty. Meanwhile, the external issues relate to poor infrastructure, lack of capital supports, and limited access. All of these constraints are believed to have accelerated the growth of shifting cultivation as the predominant upland farming practice in this area. Specific to this condition, strategies with specific characteristics are required, such as low-cost strategies to reverse the trend of low productivity, loss of sustainability, and loss of livelihood for the farming populations. Among the strategies mentioned earlier, the improvement of soil fertility by agronomic measures would be a useful and an easily-adoptable method in enhancing productivity of smallholder upland farming (De Costa and Sangakkara 2006).

Although many promising strategies are available to support upland rice developments in West Kalimantan, a suitable, specific, and economically acceptable technology package is still urgently needed. Further extensive experiments should be conducted to gain better understanding of the complex interactions among farming practices, environmental characteristics, and agro-ecosystem resilience (Gomiero 2013). It is reasonable if the technology package combines indigenous forms of lands and resource management (Yuksel 1998).

Furthermore, adding organic matter to upland soils in tropical countries is highly recommended (Magdoff 1992) as the soils are known to be very low in organic matter content, so that to create productive soils (Magdoff 1992), to maintain soil structure, water holding capacity, soil organisms, and nutrient cycle (Goulding et al. 2001), to enhance soil physical and chemical properties (Weil and Magdoff 2004), to restore the impact of mechanical impedance and to increase soil aggregate stability (Jack and Thies 2006), to increase infiltration and drainage so as to reduce soil loss due to surface runoff (Magdoff and Weil 2004). These all previous studies showed that there are many positive effects of adding organic matter to soil, making it not only critical but also compulsory to add organic matter as a component of field research in restoring upland tropical soil fertility, such as in West Kalimantan, for instance. There is still lack of information about applied specific studies on the effect of adding organic matter on soil chemical properties of highly degraded soil in West Kalimantan.

This preliminary research has been initiated to design a basic technology package to increase the growth of selected local rice variety through lowinput sustainable agriculture practice. This research attempted to use local resources, such as rice straw and cow manure for making compost, and selected local upland rice variety. This low-input technology is believed to be a potential solution to support upland rice development as part of food security efforts in West Kalimantan. 


\section{MATERIALS AND METHODS}

\section{Preparation of the Experiment}

The preparation of the experiment was started in August 2015 and the field activities were ended in February 2016. The experiment was conducted by planting selected local rice variety in polybags in the green house at the Field Research Station of the Faculty of Agriculture, Tanjungpura University. A local rice variety, known as the Ketumbar, was used as part of adopting local practice. About 5 seeds were planted in each polybag.

\section{Soil Sampling and Properties of Soil, Manure and Compost}

The soil samples were collected from the depth of $20 \mathrm{~cm}$ from upland rice fields $\left(00^{\circ} 18^{\prime} 56.9^{\prime \prime} \mathrm{N}\right.$, $109^{\circ} 16^{\prime} 35.0^{\prime \prime} \mathrm{E}$ ) which belong to a farmer in the Village of Kayu Tanam, Mandor subdistrict, Landak district, West Kalimantan. The soil samples were analyzed in the Soil Chemistry and Soil Fertility Laboratory of the Faculty of Agriculture, Tanjungpura University. All soil parameters were measured using the methods explained by Page et al. (1982). The soil properties prior to treatments were: $\mathrm{pH}=4.48$, Organic- $\mathrm{C}=1.37 \%$, total $\mathrm{N}=$ $0.18 \%, \mathrm{P}_{2} \mathrm{O}_{5}$ (Bray) $=6.67 \mathrm{ppm}$, base saturation $=$ $38.63 \%, \mathrm{CEC}=8.72 \mathrm{cmol}(+) \mathrm{kg}^{-1}, \mathrm{~K}=0.14$ $\operatorname{cmol}(+) \mathrm{kg}^{-1}, \mathrm{Na}=0.44 \mathrm{cmol}(+) \mathrm{kg}^{-}, \mathrm{Ca}=2.05$ $\mathrm{cmol}(+) \mathrm{kg}^{-1}, \mathrm{Mg}=0.74 \mathrm{cmol}(+) \mathrm{kg}^{-1}$, sand $=74.78 \%$, silt $=16.47 \%$ and clay $=8.75 \%$. The soil is considered as a highly degraded sandy soil.

Cow manure was collected from a local private cattle breeder in the Village of Bansir Darat, in the city of Pontianak. The properties of the cow manure were: $\mathrm{pH}=6.68$, organic- $\mathrm{C}=34.29 \%$, total $\mathrm{N}=$ $3.73 \%, \mathrm{C} / \mathrm{N}$ ratio $=9.19, \mathrm{P}=0.16 \%, \mathrm{~K}=0.27 \%$, $\mathrm{Ca}=3.19 \%$, and $\mathrm{Mg}=0.22 \%$. Compost was made from rice straw collected from a paddy field in the city of Singkawang. The properties of the rice straw compost were: $\mathrm{pH}=3.77$, organic- $\mathrm{C}=37.51 \%$, total $\mathrm{N}=2.71 \%, \mathrm{C} / \mathrm{N}$ ratio $=13.84, \mathrm{P}=0.65 \%, \mathrm{~K}=$ $2.20 \%, \mathrm{Ca}=1.93 \%$ and $\mathrm{Mg}=0.20 \%$.

\section{Research Design and Treatments}

The study was arranged in a Completely Randomized Design consisting of 6 treatment levels and 4 replications. The treatment levels were P0 (no treatment), P1 (7 Mg cow manure ha ${ }^{-1}+300$ kg compound NPK ha-1), P2 (15 Mg cow manure $\mathrm{ha}^{-1}+300 \mathrm{~kg}$ compound NPK ha $\left.{ }^{-1}\right)$, P3 (7 Mg rice straw compost ha- ${ }^{-1}+300 \mathrm{~kg}$ compound NPK ha-1), P4 $\left(15 \mathrm{Mg}\right.$ rice straw compost $\mathrm{ha}^{-1}+300 \mathrm{~kg}$ compound NPK ha-1), and P5 (600 kg compound
NPK ha-1). The doses of compost and cow manure used were based on the soil weight, while the dose of compound NPK fertilizers was based on the local recommendation dose. Prior to weighing cow manure, rice straw compost and compound NPK fertilizers, the total amount of soil used was calculated and determined. The cow manure and compost were prepared separately and subsequently mixed thoroughly with the soil and incubated for two weeks before being weighed and divided into poly-bags. The total weight of the soil in each polybag was equal to $8 \mathrm{~kg}$ per polybag. Inorganic fertilizers used for each treatment were compound NPK with the trade-mark of Mutiara. They were prepared and mixed a day before planting. "Full doses"of NPK amounted to $600 \mathrm{~kg}$ compound NPK ha-1, which was the dose commonly applied by the local farmers. The plant and soil parameters were determined including plant height measured in week 4, 6, 7, and 12 after planting; above-ground plant dry weight to determine the plant biomass; the uptake of N, P, K by plants; soil $\mathrm{pH}$; organic $\mathrm{C}$ content; $\mathrm{N}, \mathrm{P}, \mathrm{K}$ contents in the soil and other selected soil properties, namely $\mathrm{Ca}, \mathrm{Mg}$, $\mathrm{Na}, \mathrm{CEC}$, exchangeable-Al and -Fe at the end of the experiment.

\section{Data Analysis}

The statistical analyses were conducted according to Gomez and Gomez (2007). When there was a significant effect among the treatments, further tests were conducted using Duncan Multiple Range Test at $a_{0.05}$.

\section{RESULTS AND DISCUSSION}

\section{Rice Plant Growth}

Plant growth response, as demonstrated by plant height parameter, in each treatment was measured at the $4^{\text {th }}, 6^{\text {th }}, 7^{\text {th }}$ and $12^{\text {th }}$ week after planting and presented in Figure 1. Rice plant growth was significantly affected by the type and doses of fertilizers used. At the end of the observation period (week 12), there were significant differences in the average plant heights among all fertilizer treatments (P1, P2, P3, P4, and P5) compared to that of no input treatment (P0) (Figure 1). At week 12, the increase of plant height in the treatments of combinations of organic fertilizers and half doses of inorganic fertilizers was about 22 to $23 \%$. Moreover, the data showed that the plant growth was slightly higher in both cow manure and rice straw compost inputs that were added with half doses of commonlyapplied compound NPK than that of full doses of 

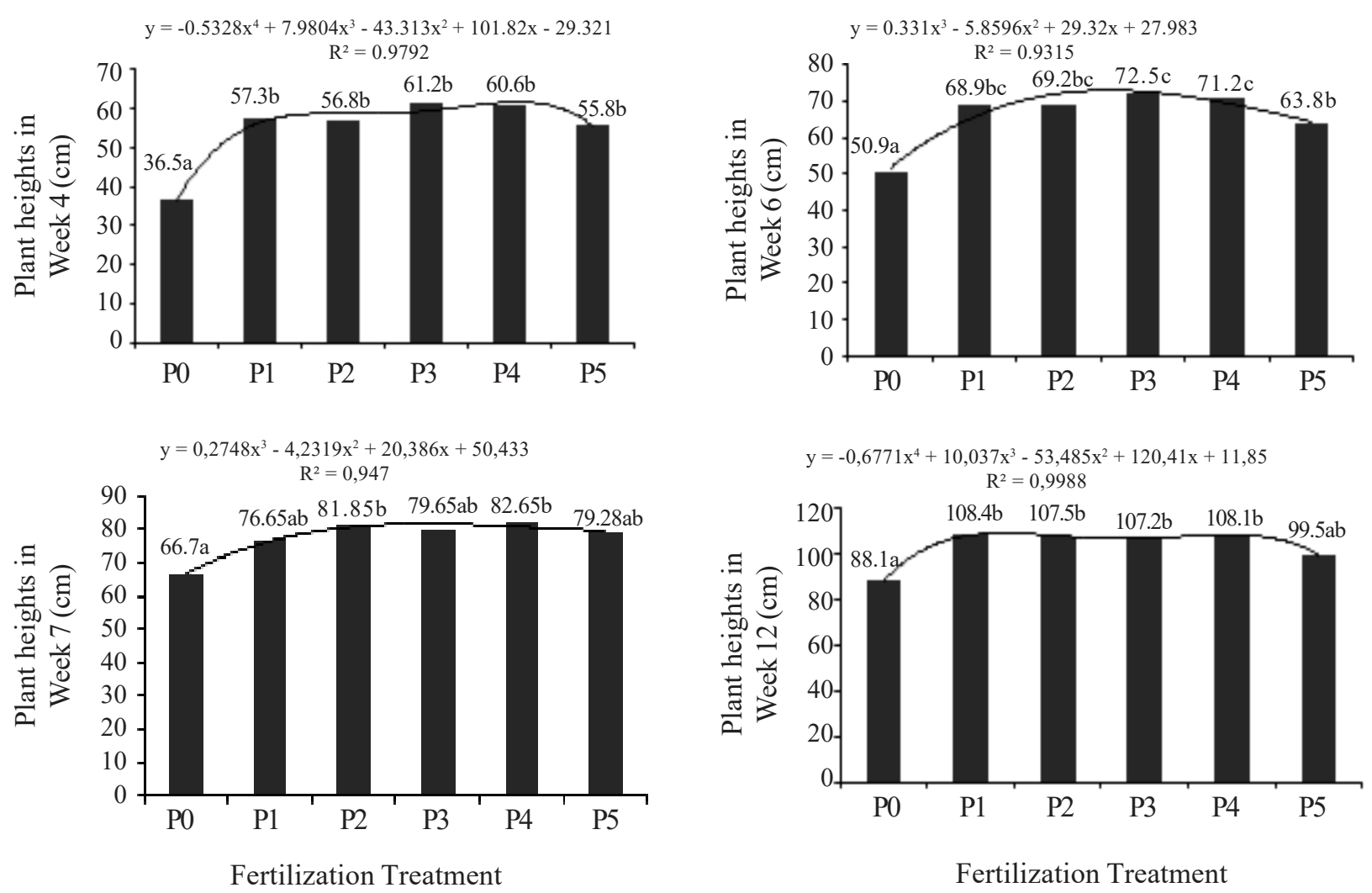

Figure 1. The height of rice plants in each fertilization treatment at 4, 6, 7, and 12 weeks after planting. : Plant height $(\mathrm{cm}), \ldots$ : Poly Plant height $(\mathrm{cm})$. The numbers above the bars followed by the same letters were not significantly different at $p=0.05$. P0: no treatment, P1: $7 \mathrm{Mg}$ cow manure $\mathrm{ha}^{-1}+300 \mathrm{~kg}^{\mathrm{NPK}} \mathrm{ha}^{-1}, \mathrm{P} 2: 15 \mathrm{Mg}$ cow manure ha- ${ }^{-1} 300 \mathrm{~kg} \mathrm{NPK} \mathrm{ha}^{-1}$, P3: $7 \mathrm{Mg}$ rice straw

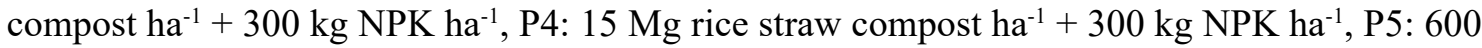
$\mathrm{kg}$ NPK ha-1.

commonly-applied compound NPK. The data on weekly rice plant growth were highly supported by the data on plant dry weight (Figure 2). Rice plant growth response to fertilizer combination treatments, either cow manure or rice straw compost of 7 and $15 \mathrm{Mg} \mathrm{ha}^{-1}$ plus $300 \mathrm{~kg}$ compound NPK ha ${ }^{-1}$, was higher than that of no input treatment, and similar to that in $600 \mathrm{~kg}$ compound NPK ha ${ }^{-1}$ treatment. It seemed that the fertilizer combination treatments have provided more nutrients needed for plant growth. The amount of cow manure and rice straw compost plus half of the recommended doses of compound NPK could support the plant growth properly. It is a positive result of the study as only few of local farmers have applied these local prospective fertilizers.

The results of current study demonstrated a similar trend to those of Ogundare et al. (2012) who reported that the combined application of poultry manure and NPK fertilizers produced the highest root biomass, shoot biomass, yield, stem girth, leaf area, and plant height of maize palnts. However, it is surprising that the rice plant growth response to the application of $600 \mathrm{~kg}$ of inorganic NPK ha- ${ }^{-1}$ was statistically similar to that of the response of all other treatments. It means that the amount of either cow manure or rice straw compost applied could substitute half doses of NPK fertilizers. A possible explanation to this phenomenon is the type of inorganic fertilizers used, which was the compound NPK fertilizers with the composition of $15 \% \mathrm{~N}, 15 \%$ $\mathrm{P}$ and $15 \% \mathrm{~K}$. It means that there was only about $90 \mathrm{~kg}$ of each N, P, K in $600 \mathrm{~kg}$ of compound NPK applied. That amount is estimated to be much lower than the plants' needs during the growth period; thus, it is why the plant response was not optimal. This type of fertilizer is preferred by the local farmers because it provides more of the major nutrients, mainly NPK, compared to that of single fertilizer type. It seems that the dose of $600 \mathrm{~kg} \mathrm{ha}^{-1}$ compound NPK was still not enough to support plant growth optimally on highly degraded sandy soil.

\section{Rice Plant Dry Weight and NPK Uptake}

The data on plant dry weight and NPK uptake are presented in Figure 2. Rice plant biomass at the end of the experiment is represented by plant dry 

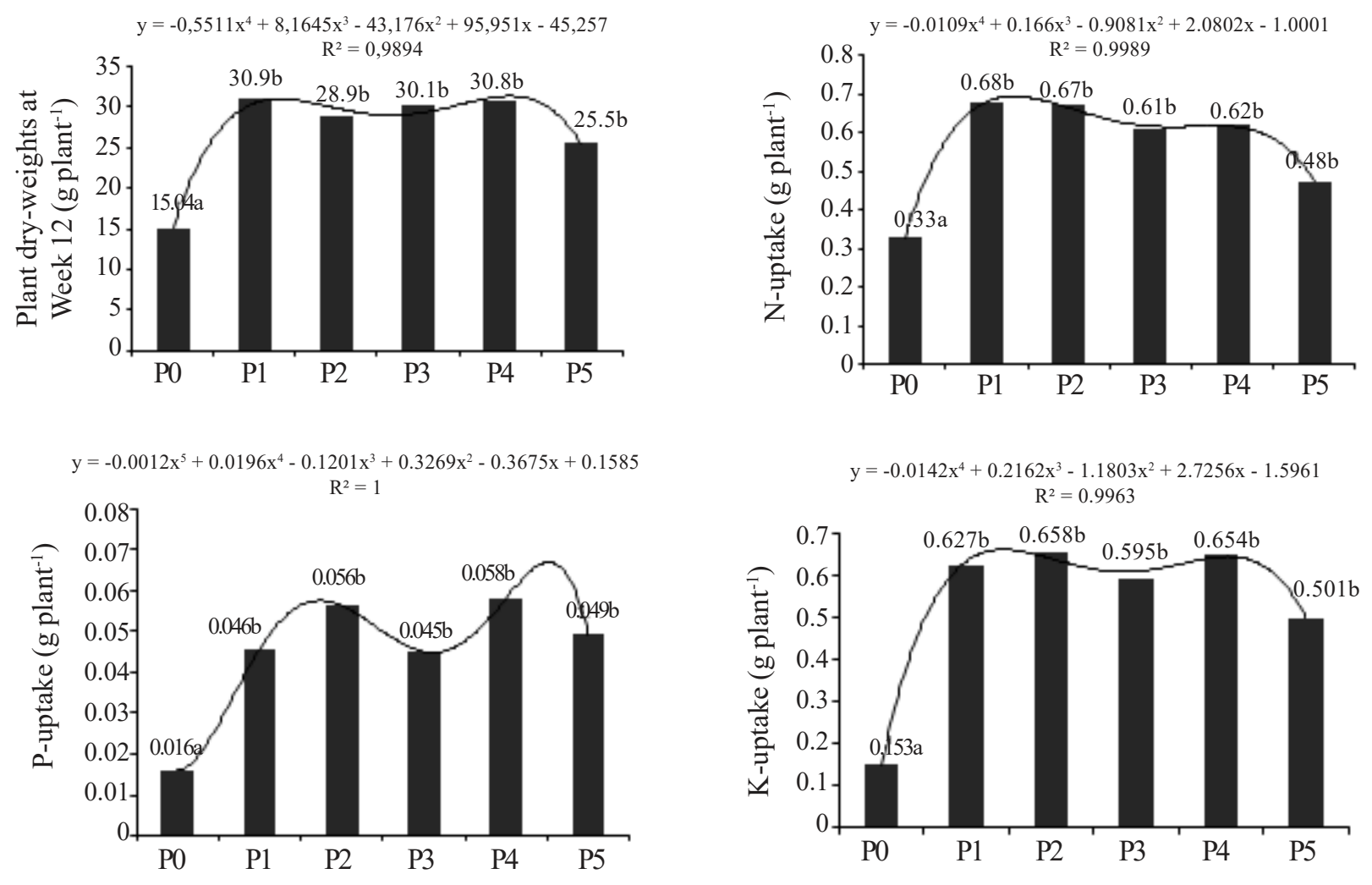

Fertilization Treatment

Fertilization Treatment

Figure 2. Above ground plant dry weight and NPK uptake by rice plants at the end of experiment. The numbers above the bars followed by the same letters were not significantly different at $p=0.05$. P0: no treatment, P1: $7 \mathrm{Mg}$ cow manure ha ${ }^{-1}+300 \mathrm{~kg} \mathrm{NPK} \mathrm{ha}^{-1}, \mathrm{P} 2: 15 \mathrm{Mg}$ cow manure ha ${ }^{-1}+300$ $\mathrm{kg} \mathrm{NPK} \mathrm{ha} \mathrm{a}^{-1}$, P3: $7 \mathrm{Mg}$ rice straw compost ha ${ }^{-1}+300 \mathrm{~kg} \mathrm{NPK} \mathrm{ha}^{-1}$, P4: $15 \mathrm{Mg}$ rice straw compost $\mathrm{ha}^{-1}+300 \mathrm{~kg}$ NPK ha- ${ }^{-1}$ P5: $600 \mathrm{~kg}$ NPK ha- .

weight. The combination of low-input fertilizer treatments significantly increased the rice plant biomass compared to that of no input treatment. The increase in rice plant biomass was about $92 \%$ to $106 \%$. This increasing trend in plant biomass due to the combined application of organic fertilizer and inorganic NPK fertilizer is supported by the findings of Ogundare et al. (2012). It illustrated that the combination of low-input application of organic and inorganic fertilizers played a significant role in promoting selected local rice plant growth in the upland soils of West Kalimantan. Although they were not statistically different, in fact, the rice plant biomass in low-input fertilizer treatments were slightly higher than those in "full doses" of compound NPK. It simply explained that the selected local upland rice responded very well to the combination of low-input fertilizer applications. By producing a similar statistic response to that of $600 \mathrm{~kg} \mathrm{ha}^{-1} \mathrm{NPK}$, it means that the use of either cow manure or rice straw compost could be an important factor for the development of upland farming in West Kalimantan. The amount of both cow manure and rice straw compost applied could substitute half doses of the recommended NPK fertilizers $\left(600 \mathrm{~kg} \mathrm{ha}^{-1}\right)$. These findings will be a prospective part of farming technology package for rural indigenous farmers in West Kalimantan because both cow manure and compost are rarely used as alternative fertilizers.

All these findings showed that using only half doses of commonly-applied NPK plus either cow manure or rice straw compost improved local upland rice growth compared to that of no input treatment, a method that is still being practiced in many rural areas of West Kalimantan. The rice plant growth in the combination treatments showed a trend of slightly higher than that of full doses of commonly-applied NPK, although they were not significantly different statistically. The use of either cow manure or rice straw compost as fertilizers in upland rice fields is rarely practiced by the indigenous local people, especially for those living in inner rural areas. Both cow manure and rice straw compost are available as local resources that should have been used proportionally to support the local upland rice farmers. The use of both local resources would be 
Table 1. Residual content of selected chemical characteristics of soils applied with different types and amounts of organic and inorganic fertilizers.

\begin{tabular}{lcccccccccccc}
\hline Variable & $\begin{array}{c}\mathrm{pH} \\
\mathrm{H}_{2} \mathrm{O}\end{array}$ & $\begin{array}{c}\text { Org-C } \\
(\%)\end{array}$ & $\begin{array}{c}\text { Total } \\
(\%)\end{array}$ & $\begin{array}{c}\mathrm{P}_{2} \mathrm{O}_{5} \\
(\mathrm{ppm})\end{array}$ & $\mathrm{K}$ & $\mathrm{Ca}$ & $\mathrm{Mg}$ & $\mathrm{Na}$ & $\mathrm{CEC}$ & $\begin{array}{c}\text { Exch } \\
-\mathrm{Al}\end{array}$ & $\begin{array}{c}\mathrm{Fe} \\
\left(\mathrm{cmol}(+)\left(\mathrm{kg}^{-1}\right)\right.\end{array}$ \\
\hline Treatment Level & & & & & & & & & & & & \\
P0 & 4.44 & 1.13 & 1.07 & 38.6 & 0.03 & 0.31 & 0.10 & 0.06 & 6.61 & 0.07 & 13.91 \\
P1 & 4.38 & 1.11 & 0.51 & 35.5 & 0.03 & 0.29 & 0.10 & 0.06 & 6.37 & 0.12 & 12.88 \\
P2 & 4.45 & 1.10 & 0.81 & 38.8 & 0.03 & 0.28 & 0.09 & 0.05 & 6.14 & 0.07 & 13.01 \\
P3 & 4.74 & 1.10 & 0.60 & 55.9 & 0.04 & 0.33 & 0.11 & 0.08 & 6.37 & 0.03 & 13.02 \\
P4 & 4.54 & 1.25 & 0.64 & 35.6 & 0.05 & 0.39 & 0.13 & 0.09 & 6.61 & 0.07 & 13.03 \\
P5 & 4.72 & 1.04 & 0.55 & 34.3 & 0.03 & 0.22 & 0.07 & 0.06 & 5.94 & 0.05 & 13.43 \\
\hline Tukey-HSD & NS & NS & NS & NS & NS & NS & NS & NS & NS & NS & NS \\
\hline
\end{tabular}

Note: $* \mathrm{NS}=$ not significant. P0: no treatment, P1: $7 \mathrm{Mg}$ cow manure ha ${ }^{-1}+300 \mathrm{~kg} \mathrm{NPK} \mathrm{ha}^{-1}, \mathrm{P} 2: 15 \mathrm{Mg}_{\text {cow manure }}$ $\mathrm{ha}^{-1}+300 \mathrm{~kg} \mathrm{NPK} \mathrm{ha}^{-1}, \mathrm{P} 3: 7 \mathrm{Mg}$ rice straw compost ha ${ }^{-1}+300 \mathrm{~kg} \mathrm{NPK} \mathrm{ha}^{-1}, \mathrm{P} 4: 15 \mathrm{Mg}$ rice straw compost $\mathrm{ha}^{-1}+300 \mathrm{~kg} \mathrm{NPK} \mathrm{ha}^{-1}$, P5: $600 \mathrm{~kg} \mathrm{NPK} \mathrm{ha}^{-1}$.

advantageous because the commercial fertilizers are not only expensive but also scarce in the rural areas of West Kalimantan. The use of organic fertilizers, such as cow manure and compost, is highly recommended as it is known to be useful to replace nutrient supply and carbon sequestration (Seiter and Horwath 2004; Blanco et al. 2013), to improve soil quality (Gomiero 2013), to restore the productivity of marginal soils (Hornick and Parr 1987), to sustain soil organic matter (Rees et al. 2001), to prevent soil organic matter decline and possible ecosystem collapse (Raupp 2001; Smith and Collin 2007), and to enhance soil microbial activities (Abbot and Murphy 2007). Furthermore, it was also explained that adding organic matter from external sources is considered to be the best option for increasing soil organic matter content, nutrient level, and sustainability of tropical smallholding upland cropping systems (Costa and Sangakkara 2006). The results of this study showed that the rice straw compost left higher amount of base cation residues at the end of the experiment compared to that of $600 \mathrm{~kg}$ $\mathrm{ha}^{-1}$ NPK fertilizers. Adding organic matter could enhance the amount of nutrient residues in the highly degraded sandy soil in West Kalimantan (Table 1).

Figure 2 also showed that the combinations of low input inorganic and organic fertilizers significantly affected NPK uptake by the rice plants compared to the control treatment. The NPK uptake significantly increased in most of fertilizer treatments compared to those in no input treatments. The increase of $\mathrm{N}$ uptake is in the range of $85 \%$ to $106 \%$, the increase of $\mathrm{P}$ uptake is in the range of $181 \%$ to $262 \%$, and the increase of $\mathrm{K}$ uptake is in the range of $289 \%$ to $327 \%$. The uptake of $\mathrm{N}$ and $\mathrm{K}$ in the upland rice plants showed a similar pattern to those of plant dry weight (Figure 1). It is surprising that the trend of $\mathrm{N}$ and $\mathrm{K}$ uptake was slightly higher in the combination of fertilizer treatments compared to that of full doses of commonly-applied NPK, even though they were not significantly different, except that to the control treatment. The results showed that the use of cow manure and rice straw compost could replace the half doses of compound NPK fertilizers. It is a promising result for the local farmers in West Kalimantan because so far they have not used these local materials proportionally and intensively. The positive result of the current study was similar to the findings of Eghball et al. (2004), which showed that the fertilizer treatment resulted in greater $\mathrm{N}$ uptake than the control treatment. However, the increasing trend in $\mathrm{N}$ uptake in the current study is in contrast with the findings of Cogger (2005), which proposed that compost application did not affect $\mathrm{N}$ uptake during the establishment year, although it did increase in the subsequent years.

On the other hand, P uptake showed a specific trend that its uptake seemed to be more dependent on the amount of organic fertilizers applied. The more the organic fertilizer applied, the higher the $\mathrm{P}$ uptake by the rice plant is. In cow manure treatments, the P uptake increased from $187 \%$ to $250 \%$ when the amount applied was increased from 7 to $15 \mathrm{Mg}$ $\mathrm{ha}^{-1}$, while in the rice straw compost treatment, the P uptake increased from $181 \%$ to $263 \%$ when the amount applied was increased from 7 to $15 \mathrm{Mg}$ $\mathrm{ha}^{-1}$. The increase in NPK uptake was supported by the rice plant growth response. Again, it explained that the low-input combination of fertilizer treatments 
significantly increased NPK uptake by the local upland rice plants. These findings supported a previous publication, which stated that the application of inorganic fertilizers combined with organic manure improved crop P uptake, maintained soil's P level, and reduced $P$ losses (Mao et al. 2015).It seems that the choice of using compound NPK fertilizers is a local knowledge to support low-input sustainable agricultural practices in the rural areas of West Kalimantan. Rural farmers prefer to use this NPK compound fertilizers because it has higher major nutrient contents. In general, these findings demonstrated a similar trend to the research findings of Chivenge et al. (2011), which explained that the growth and yield responses of maize were positively influenced by the addition of organic matter, $\mathrm{N}$ fertilizer, and organic matter combined with $\mathrm{N}$ fertilizer.

\section{The NPK Contents in Soil and Other Selected Soil Chemical Properties.}

The NPK contents in the soil, soil $\mathrm{pH}$, organic$\mathrm{C}$ content, cation-exchange capacity, exchangeable base cations, Fe content, and exchangeable Al were measured at the end of the experiment and presented in Table 1. The aim was to observe the residues in the soil after the experiment was stopped.

Table 1 showed that there were no significant effects of different types and combinations of fertilizer treatments on the soil chemical properties such as soil $\mathrm{pH}$, organic $\mathrm{C}$ content, total $\mathrm{N}, \mathrm{P}, \mathrm{K}$ content, cation-exchange capacity, exchangeable base cations, exchangeable $\mathrm{Al}$, and $\mathrm{Fe}$ content. These results are as expected because it is a preliminary establishment year of infertile highly degraded upland soil, so not much residue would be left in the soil. These phenomena clearly illustrated how low-input fertilizer treatments left less chemical residues in the soil, as a result, most of available nutrients might have been used for plant growth or part of them might have been leached and lost from the soil. Even though the treatments did no resulted in significant effects, most of the observed soil chemical properties, such as soil $\mathrm{pH}$, organic-C contant, base cations, and CEC showed increasing trends, except for total $\mathrm{N}$, exchangeable $\mathrm{Al}$, and $\mathrm{Fe}$ content. The increasing trend in the amount of organic C, CEC, and base cations left in the soil follows the findings of Santillan et al. (2014). The trend of increasing soil organic $\mathrm{C}$ content is also similar to the findings of Chivenge et al. (2011). These findings provided positive and meaningful information as they helped to determine how much residue from each treatment remained in the soil at the end of the experiment. These strategic figures will be useful to direct the next important step in designing both a further upland soil field study and low-input farming strategic research in West Kalimantan.

Furthermore, it seemed that $15 \mathrm{Mg} \mathrm{ha}^{-1}$ of cow manure plus half of commonly-applied NPK provided higher total $\mathrm{N}$ than other fertilizer treatments. The low $\mathrm{C} / \mathrm{N}$ ratio in cow manure might have made it more abundant in the soil, making it easier to be absorbed and leached away. Therefore, it is not surprising when the NPK uptake increased significantly (Figure 2). Moreover, these findings also showed that $\mathrm{N}$ added from all fertilizer treatments might not be enough to fulfill the rice plants' needs during their growth period as very little was left as residue in the soil (Table 1). Furthermore, $15 \mathrm{Mg}$ $\mathrm{ha}^{-1}$ of rice straw compost plus half dose of commonly-applied NPK left the highest K and other base cation residues in the soil, such as $\mathrm{Ca}, \mathrm{Mg}$, and $\mathrm{Na}$. It supports the common knowledge that the rice straw is a good source for increasing soil $\mathrm{K}$ level. The results of rice straw compost and cow manure analyses supported this point of view as rice straw compost contains $2.2 \% \mathrm{~K}$, while cow manure contains only $0.27 \% \mathrm{~K}$. For this experiment, the increase of the base cations might have caused the slight increase in soil $\mathrm{pH}$. It also supports a previous study that presented that the application of manure could also increase the $\mathrm{pH}$ of acidic soil (Whalen et al. 2000). It also explained that the application of manure and compost not only improved the soil properties for several years after its application but also provided nutrients and liming effects. However, the increase in soil $\mathrm{pH}$ could be a temporary effect, as the long-term effect of compost addition caused a decrease in soil $\mathrm{pH}$ (Eghball et al. 2004). As local upland rice has been known to be relatively tolerant to low soil $\mathrm{pH}$, the use of rice straw compost was highly recommended to fulfill base cations for plant growth. Another reason for this suggestion was that there are no natural sources of lime in West Kalimantan, making a liming program expensive to increase soil $\mathrm{pH}$. Last but not least, it is likely that the organic fertilizer treatments in this experiment caused a decrease in soil $\mathrm{Fe}$ content and exchangeable $\mathrm{Al}$ (Table 1). These effects might have not been considered in the beginning. However, it is likely that the use of both cow manure and rice straw compost may be a potential method to minimize the detrimental effects of excessive $\mathrm{Fe}$ and $\mathrm{Al}$ contents in the upland soils for potential crops in West Kalimantan. 
The case of low P residue in the soil (Table 1) demonstrated that the addition of low-input organic and inorganic fertilizers was not enough to rebuild either total $\mathrm{P}$ or available $\mathrm{P}$ stocks in infertile upland paddy soil during the first establishment year. This upland paddy soil contained only $6.65 \mathrm{ppm}$ $\mathrm{P}_{2} \mathrm{O}_{5}$ based on Bray-1 test, while the cow manure and rice straw compost only contained $0.16 \%$ and $0.65 \% \mathrm{P}$, respectively. It seemed that the addition of organic fertilizer in combination with inorganic fertilizers was only enough to maintain the soils' $\mathrm{P}$ level, similar to that of no input treatment. However, in a long-term field trial, the addition of manure and inorganic fertilizers lead to a buildup in the soils' total $\mathrm{P}$ and available $\mathrm{P}$ stocks (Mao et al. 2015) and an increase of soil nitrogen concentration and soil phosphorus availability (Santillan et al. 2014). This result proposed that the continuous application of low-input manure and compost is needed to replenish infertile upland paddy soils in the rural areas of West Kalimantan.

It is realized that this experiment is a preliminary study on the improvement of infertile upland paddy soil. It was designed to address the question of whether the selected local rice variety is responsive to low-input amendments in upland paddy soil. The findings are as expected that the selected local upland rice in West Kalimantan responded well to the combined fertilization either using cow manure or rice straw compost plus low-input inorganic NPK fertilizers. It has been interesting and promising information, because it is a common knowledge among scholars that the local rice varieties are not or are less responsive to fertilizer applications. Although they left less residue in the soil, the use of combined fertilization as designed in this study showed prospects of the use of cow manure and rice straw compost to support sustainable low-input agricultural practices in West Kalimantan. Previously, the use of organic and inorganic fertilizer combination was suggested, especially to replenish unproductive sandy upland soils (Gona 2009). Overall, from local farmers' point of view, the results of this experiment will increase their expectations in practicing low-input farming technology in rural areas, especially in West Kalimantan, since it promotes the use of local resources such as cow manure and rice straw for making compost. It has become more promising because organic amendments can be viewed as the first step for land managers toward transitioning to long-term sustainable use of damaged ecosystems (Larney et al. 2011). It also explained from both agronomic and environmental perspectives that the combined applications of inorganic $\mathrm{P}$ and organic manure are a promising agronomic strategy for increasing soil $\mathrm{P}$ availability and reducing $\mathrm{P}$ loss from the crop rotation system (Mao et al. 2015). However, the combination of manure and compost needs further intensive studies so that their complementary effects could be optimized to support the reestablishment of unproductive highly degraded upland soils in West Kalimantan.

\section{CONCLUSIONS}

The local selected upland rice has responded positively to the combination of low-input inorganic and organic fertilizers compared to that of no input treatment and commonly applied recommended NPK fertilizers. The amount of cow manure and rice straw compost applied plus half doses of inorganic compound NPK could save half doses of the recommended NPK fertilizers. Both treatments of $15 \mathrm{Mg}$ cow manure ha ${ }^{-1}$ and $15 \mathrm{Mg}$ rice straw compost ha ${ }^{-1}$, each added with $300 \mathrm{~kg}$ compound NPK ha ${ }^{-1}$, are suggested for further field research in upland soils of West Kalimantan. It was also found that both cow manure and rice straw compost treatments could enhance the residue of nutrient content in the sandy soil. Rice straw compost treatment could increase the residue of base cations, especially $\mathrm{Ca}, \mathrm{Na}$, and $\mathrm{Mg}$. However, it is still suggested to include liming in designing the technology package for further field research on re-establishing highly degraded upland soil.

\section{ACKNOWLEDGEMENTS}

We thank the Directorate General of Higher Education and the Rector of Tanjungpura University for supporting this research through the Pra Guru Besar Research Grant. We also thank Suzilawati for her field and laboratory works, and for the reviewers for their fruitful critics and suggestions.

\section{REFERENCES}

Blanco JM, C Lazcano, TH Christensen, P Muñoz, J Rieradevall, J Møller, A Antón and A Boldrin. 2013. Compost benefits for agriculture evaluated by life cycle assessment. Agron Sustain Dev 33: 721-732. doi 10.1007/s13593-013-0148-7

Badan Pusat Statistik (BPS). 2014. Kalimantan Barat Dalam Angka Tahun 2014. Badan Pusat Statistik, Provinsi Kalimantan Barat. Pontianak. (in Indonesian).

Chivenge P, B Vanlauwe and J Six. 2011. Does the combined application of organic and mineral nutrient sources influence maize productivity? A meta-analysis. Plant Soil 342: 1-30. 
Cogger CG. 2005. Potential compost benefits for restoration of soils disturbed by urban development. Compost Sci Util 13: 243-251.

De Costa and Sangakkara. 2006. Agronomic regeneration of soil fertility in tropical Asian Smallholder uplands for sustainable food production. J Agri Sci 144: 111-113.

Eghball B, D Ginting and JE Gilley. 2004. Residual effects of manure and compost applications on corn production and soil properties. Agron J 96: 442447.

Gomiero T. 2013. Alternative land management strategies and their impact on soil conservation. Agriculture 3: 464-483. doi: 10.3390/agriculture3030464.

Gomez KA and AA Gomez. 2007. Prosedur Statistik Untuk Penelitian Pertanian. Penerjemah: Endang Sjamsuddin dan Justika S. Baharsjah. Penerbit Universitas Indonesia. Jakarta. (in Indonesian).

Gona AK. 2009. Evaluation of the residual effect of cattle manure combinations with inorganic fertilizer and chemical weed control on the sustainability of chewing sugarcane production at Badeggi Southern Guinea Savanna of Nigeria. Middle-East J Sci Res 4:282-287.

Goulding KWT, DV Murphy, A Macdonald, EA Stockdale, JL Gaunt, L Blake, G Ayaga and P Brookes. 2001. The role of soil organic matter and manures in sustainable nutrient cycling. In: RM Rees, BC Ball, CD Campbell and CA Watson (eds). Sustainable Management of Soil Organic Matter. CABI Publishing. New York. USA. pp. 221-342.

Hornick SB and JF Parr. 1987. Restoring the productivity of marginal soils with organic amendment. $A m J$ Alternative Agr 2: 64-68.

Jack Allison LH and JE Thies. 2006. Compost and vermicompost as amendments promoting soil health. In: Norman Uphoff et al. (eds). Biological Approaches to Sustainable Soil Systems. CRC Press, Boca Raton, FL. USA.

Killham K. 2011. Integrated soil management-moving towards globally sustainable agriculture. $J$ Agric Sci 149: 29-36. doi: 10.1017/S0021859610000845.

Larney FJ, HH Janzen and AF Olson. 2011. Residual effects of one-time manure, crop residue and fertilizer amendments on a desurfaced soil. Can J Soil Sci 91:1029-1043. doi:10.4141/CJSS10065.

Magdoff F. 1992. Building Soils for better crops-organic matter management. University of Nebraska Press. Lincoln and London.

Magdoff F and RR Weil. 2004. Soil Organic Matter Management Strategies. In: F Magdoff and RW Ray (eds). Soil Organic Matter in Sustainable Agriculture. CRC Press. Boca Raton, London, New York, Washington, D.C.

Mao, Xiali, X Xu, K Lu, G Gielen, J Luo, L He, ADonnison, Z Xu, J Xu, W Yang, Z Song and H Wang. 2015. Effect of 17 years of rganic and inorganic fertilizers applications on soil phosphorus dynamics in a rice- wheat rotation cropping system in Eastern China. $J$ Soils Sediments 15:1889-1899.

Montagnini F.2001. Strategies for the recovery of degraded ecosystems: experiences from latin America. Intercencia, Agric J 26: 498-503.

Ogundare K, S Agale and P Aiyelari. 2012. Organic amendment of an ultisol: effects on soil properties, growth, and yield of maize in Southern Guinea savanna zone of Nigeria. Int J Recyc Organic Waste in Agric 1: 11. http://www.ijrowa.com/content/1/1/ 11.

Page AL, RH Miller and DR Keeney. 1982. Methods of Soil Analysis. Part 2. Chemical and Microbiological Properties. Second Edition. Number 9 (Part 2) in the seies Agronomy. American Society of Agronomy, Inc, Soil Science Society of America, Inc. Publisher. Madison, Wisconsin, USA.

Phillips SL and MS Wolfe. 2005. Evolutionary plant breeding for low input systems. J Agric Sci 143: 245-254.

Raupp J. 2001. Manure fertilization for soil organic matter maintenance and its effects upon crops and the Environment, Evaluated in a Long-Term Trial. In: RM Rees, BC Ball, CD Campbell and CA Watson (eds). Sustainable Management of Soil Organic Matter. CABI Publishing. New York. USA.

Rees RM, BC Ball, CD Campbell and CA Watson. 2001. Sustaining soil organic matter. In: RM Rees, BC Ball, CD Campbell and CA Watson (eds). Sustainable management of soil organic matter. CABI Publishing. New York. USA.

Regmi PP and KE Weber. 2000. Problem to agricultural sustainability in developing countries and a potential solution: Diversity. Int J Soc Eco 27: 788-801.

Santillán YM, FP Moreno, FP Garcia and OAA Sandoval. 2014. Effect of the application of manure of cattle on the properties chemistry of soil in Tizayuca, Hidalgo, Mexico. Int J Appl Sci Tech 4: 67-72.

Seiter S and WR Horwath. 2004. Strategies for managing soil organic matter to supply plant nutrients. In: F Magdoff and RW Ray (eds). Soil Organic Matter in Sustainable Agriculture. CRC Press. Boca Raton, London, New York, Washington, D.C.

Smith LJ and HP Collin. 2007. Management of organisms and their processes in soils. In: EA Paul (ed). Third Edition. Soil Microbiology, Ecology, and Biochemistry. Academic Press. Amsterdam, New York.

Thierfelder C, L Rusinamhodzi, AR Ngwira, W Mupangwa, I Nyagumbo, GT Kassie and JE Cairns. 2014. Conservation agriculture in Southern Africa: Advances in knowledge. Renew Agr Food Syst 30: 328-348.

Weil RR and F Magdoff. 2004. Significance of soil organic matter to soil quality and health. In: F Magdoff and RW Ray (eds). Soil Organic Matter in Sustainable Agriculture. CRC Press. Boca Raton, London, New York, Washington, D.C. 
Whalen JK, Ch Chang, GW Clayton and JP Carefoot. 2000. Cattle manure amendments can increase the pH of acid soils. Soil Sci Soc Am J 64: 962-966.

Wolfe MS. 2000. Crop strength through diversity. Nature 406: 681-682.
Yuksel N. 1998. Coping with environmental degradation in the tropics: indigenous strategies to sustainable development. A Thesis submitted to the Faculty of Graduate Studies and Research. Carleton University, Ottawa, Ontario. 